\title{
PERSEPSI PETANI PADI SAWAH TERHADAP KINERJA PENYULUH PERTANIAN DI DESA TATENGESAN KECAMATAN PUSOMAEN KABUPATEN MINAHASA TENGGARA
}

\author{
Anggi Ravy Tanauma \\ Welson Marthen Wangke \\ Elsje Pauline Manginsela
}

\begin{tabular}{ll}
\hline Naskah diterima melalui Website Jurnal Ilmiah agrisosioekonomi@ unsrat.ac.id & : Jumat, 12 Juli 2019 \\
Disetujui diterbitkan & : Senin, 22 Juli 2019 \\
\hline
\end{tabular}

\begin{abstract}
This study aims to determine the perceptions of farmers in rice fields on the performance of agricultural extension workers in Tatengesan Village, Pusomaen District, Southeast Minahasa Regency. This research was conducted for 3 months from March to May 2019. The data used in this study are primary data and secondary data. Primary data collection through interviews and filling out questionnaires with 9 direct questions to 20 respondents of lowland rice farmers. Secondary data was obtained from related institutions, namely the Agricultural Extension Office (BPP), the Old Law Office and the Pusomaen District Office of Southeast Minahasa Regency, the Internet through google searching and google book, to obtain journal books and articles related to research topics, namely perceptions of lowland rice farmers on the performance of agricultural extension agents. Data analysis carried out in the study was descriptive analysis using a Likert Scale. The results of the study using a Likert Scale showed that the index numbers of perceptions of lowland rice farmers on the performance of agricultural extension workers were at the point of $57.96 \%$ which was included in the satisfied category. ${ }^{*}{ }^{\text {eprm* }}$
\end{abstract}

Keywords: perceptions of farmers, performance of extension agents, Tatengesan Village, Southeast Minahasa Regency.

\begin{abstract}
ABSTRAK
Penelitian ini bertujuan untuk mengetahui persepsi petani pada sawah terhadap kinerja penyuluh pertanian di Desa Tatengesan Kecamatan Pusomaen Kabupaten Minahasa Tenggara. Penelitian ini dilaksanakan selama 3 bulan dari bulan March sampai Mei 2019. Data yang digunakan dalam penelitian ini adalah data primer dan data sekunder. Pengumpulan data primer melalui wawancara dan mengisi kuesioner dengan 9 pertanyaan langsung kepada 20 responden petani padi sawah. Data sekunder diperoleh dari instansi terkait yaitu kantor Balai Penyuluh Pertanian (BPP), Kantor Hukum Tua dan Kantor Kecamatan Pusomaen Kabupaten Minahasa Tenggara, Internet melalui google searching dan google book, untuk mendapatkan buku dan artikel jurnal yang berkaitan dengan topic penelitian yaitu persepsi petani padi sawah terhadap kinerja penyuluh pertanian. Analisis data yang dilakukan dalam penelitian adalah analisis deskripstif dengan menggunakan Skala Likert. Hasil penelitian dengan menggunakan Skala Likert menunjukkan bahwa angka indeks persepsi petani padi sawah terhadap kinerja penyuluh pertanian berada pada titik 57,96\% yang masuk pada kategori puas. ${ }^{*}$ prm*
\end{abstract}

Kata kunci: persepsi petani, kinerja penyuluh, Desa Tatengesan, Kabupaten Minahasa Tenggara.

\section{PENDAHULUAN}

\section{Latar Belakang}

Pembangunan di negara yang sedang berkembang pada umumnya dititik beratkan pada sektor pertanian guna mmperbaiki mutu makanan penduduknya dan untuk memenuhi kebutuhan bahan pangan secara nasional (Kementrian Pertanian 2014). Salah satu upaya pemerintah untuk mewujudkan sektor pertanian menjadi sebuah sektor yang maju adalah dengan cara melakukan pengesahan UU No.16 tahun 2006 mengenai sistem penyuluh pertanian, perikanan dan kehutanan di Indonesia. 
Pemerintah menyadari pentingnya keberadaan penyuluh pertanian dalam rangka membantu pemerintah untuk meningkatkan sektor pertanian, karena penyuluh pertanian adalah orang yang langsung berinteraksi dan berhadapan langsung dengan petani. Kegiatan penyuluhan pertanian dilakukan untuk membantu mengatasi berbagai permasalahan yang dihadapi para petani.(Gitosaputro, Listiana, dan Gultom,2012).

Kompetensi penyuluh pertanian perlu mendapat perhatian yang serius, karena peningkatan dan penurunannya akan berpengaruh langsung terhadap peningkatan dan penurunan kinerja penyuluh. (Arimbawa dalam Animar, 2013).

Desa Tatengesan adalah Desa yang berada di Kecamatan Pusomaen Kabupaten Minahasa Tenggara, Sulawesi Utara, Indonesia. Dengan luas wilayah $450 \mathrm{Ha}$ dan sebagian besar penduduk bermata pencarian sebagai petani. Data Balai Penyuluhan Pertanian (BPP) jumlah penyuluh PNS di Kecamatan Pusomaen berjumlah tiga orang dan masing-masing memegang 2 dan 3 wilayah kerja.

Untuk itu penelitian ini ingin mengetahui apakah gejala yang sama terjadi juga dan bagaimana Persepsi Petani Terhadap Kinerja Penyuluh di Desa Tatengesan Kecamatan Pusomaen Kabupaten Minahasa Tenggara.

\section{Konsep Kinerja Penyuluh Pertanian}

Kinerja penyuluh adalah hasil yang di capai dari apa yang menjadi tugas dan tanggung jawab sebagai penyuluh PNS. Adapun indikator kinerja penyuluh pertanian yaitu kunjungan ke wilayah yang menjadi binaan penyuluh, program kerja yang dibuat, pelaporan yang dilakukan dari setiap kegiatan yang dilakukan, kedisiplinan penyuluh dalam menjalankan tugas dan tanggung jawabnya sebagai penyuluh PNS, materi penyuluhan serta metode yang digunakan penyuluh dalam melakukan kegian penyuluhan. (Arimbawa, Animar. 2013).

Metode penyuluhan menurut keadaan psiko-sosial sasarannya dibedakan dalam tiga hal, yaitu : 1) pendekatan perorangan, artinya penyuluh berkomunikasi secara pribadi orang seorang dengan setiap sasarannya, misalnya melalui kunjungan rumah dan kunjungan di tempat-tempat kegiatan sasarannya, 2) pendekatan kelompok, artinya penyuluh berkomunikasi dengan kelompok sasaran pada waktu yang sama, seperti pada pertemuan di lapangan, penyelenggaraan latihan dan lain-lain, 3) pendekatan massal, artinya jika penyuluh berkomunikasi secara tidak langsung dengan sejumlah sasaran yang sangat banyak bahkan mungkin tersebar tempat tinggalnya, misalnya lewat televisi, penyebaran selebaran, radio dan lain-lain. Materi penyuluhan yang disampaikan oleh penyuluh, pertama-tama harus diingat bahwa materi harus selalu mangacu pada kebutuhan yang telah dirasakan oleh masyarakat sasarannya. (Mardikanto, 2008).

\section{Peran Penyuluh Pertanian}

Penyuluhan merupakan keterlibatan seseorang untuk melakukan komunikasi informasi secara sadar dengan tujuan membantu sasarannya memberikan pendapat sehingga dapat membuat keputusan yang benar. Kegiatan tersebut dilakukan oleh seseorang yang disebut penyuluh pertanian (Van Den Ban dan Hawkins, 1999).

\section{Rumusan Masalah}

Bagaimana persepsi petani padi sawah terhadap kinerja penyuluh pertanian di Desa Tatengesan Kecamatan Pusomaen Kabupaten Minahasa Tenggara?

\section{Tujuan Penelitian}

Untuk mengetahui persepsi petani pada sawah terhadap kinerja penyuluh pertanian di Desa Tatengesan Kecamatan Pusomaen Kabupaten Minahasa Tenggara.

\section{Manfaat Penelitian}

Manfaat dari penelitian ini adalah

1. Bagi peneliti dapat melatih cara berpikir serta menganalisis data, dan penelitian ini merupakan salah satu syarat untuk memperoleh gelar sarjana di Fakultas Pertanian Universitas Sam Ratulangi, Manado.

2. Bagi penyuluh, untuk meningkatkan kinerja penyuluhan di Desa.

3. Bagi peneliti lain, dapat dijadikan referensi kajian dalam bidang penelitian yang sama. 


\section{METODE PENELITIAN}

\section{Tempat dan Waktu Penelitian}

Penelitian ini dilaksanakan selama 3 bulan dari bulan Maret sampai dengan bulan Mei 2019, mulai dari persiapan sampai dengan penyusunan laporan hasil penelitian. Tempat penelelitian dilaksanakan di Desa Tatengesan, Kecamatan Pusomaen Kabupaten Minahasa Tenggara.

\section{Metode Pengumpulan Data}

Metode pengumpulan data yang dilakukan pada penelitian ini adalah metode survei yaitu penelitian yang dilakukan untuk memperoleh fakta-fakta dan keterangan secara faktual dari sampel atau sebagian dari populasi menggunakan kuesioner sebagai alat pengumpul data.

Jenis data yang diambil adalah data primer dan data sekunder. Pengambilan data primer dilakukan dengan cara wawancara kepada masyarakat petani yang menjadi sampel penelitian menggunakan daftar pertanyaan yang telah disiapkan oleh peneliti. Data sekunder diperoleh dari instansi terkait yaitu kantor Balai Penyuluh Pertanian (BPP), kantor Hukum Tua dan kantor Kecamatan Pusomaen Kabupaten Minahasa Tenggara, buku, artikel, jurnal, internet.

\section{Metode Pengambilan Sampel}

Metode pengambilan sampel dilakukan dengan cara random sampling yaitu teknik penentuan sampel dengan menggabungkan semua subjek-subjek didalam populasi sehingga semua subjek dianggap sama dan diambil secara acak. Dari 195 populasi masyarakat petani diambil sampel sebanyak 20 responden penelitian.

\section{Konsep Pengukuran Variabel}

Adapun variabel yang diteliti adalah :

1. Program Penyuluh Pertanian
a. Sesuai dengan kebutuhan petani (3)
b. Hanya sebagai dasar kebutuhan petani (2)
c. Tidak sesuai dengan kebutuhan petani (1)

2. Rencana kerja Penyuluh Pertanian
a. Ada rencana kerja penyuluh lengkap di wilayah (3)
b. Ada rencana kerja tetapi tidak lengkap (2)
c. Tidak ada rencana kerja (1)

3. Peta wilayah untuk pengembangan teknologi dan perwilayahan komoditi unggul.

a. Ada peta wilayah kerja lengkap (3)

b. Ada peta wilayah kerja tetapi kurang lengkap (2)

c. Tidak ada peta wilayah kerja (1)

4. Penyebaran teknologi pertanian a. Penyebaran teknologi pertanian oleh penyuluh merata (3)

b. Penyebaran teknologi pertanian kurang merata (2)

c. Penyebaran teknologi pertanian tidak merata (1)

5. Upaya penyuluh pertanian lapangan untuk meningkatkan daya saing petani/kelompok tani

a. Penyuluh pertanian lapangan berupaya meningkatkan daya saing petani (3)

b. Penyuluh pertanian lapangan kurang berupaya meningkatkan daya saing petani (2)

c. Penyuluh pertanian lapangan tidak berupaya meningkatkan daya saing petani (1)

6. Upaya penyuluh pertanian lapangan untuk menjalin kemitraan petani/kelompok tani dengan pengusaha.

a. Penyuluh pertanian lapangan tetap mengupayakan kemitraan petani atau kelompok tani dengan pengusaha (3)

b. Penyuluh pertanian lapangan kurang mengupayakan kemitraan petani atau kelompok tani dengan pengusaha (2)

c. Penyuluh pertanian lapangan tidak mengupayakan kemitraan petani atau kelmpok tani dengan pengusaha (1)

7. Upaya penyuluh pertanian lapangan membuka akses petani ke lembaga keuangan, informasi, sarana produksi pertanian dan pemasaran

a. Penyuluh pertanian lapangan tetap mengupayakan membuka akses petani ke lembaga keungan, informasi, sarana produksi pertanian dan pemasaran (3)

b. Penyuluh pertanian lapangan kurang mengupayakan membuka akses petani ke lembaga keungan, informasi, sarana produksi pertanian dan pemasaran (2)

c. Penyuluh pertanian lapangan tidak mengupayakan membuka akses petani ke lembaga keungan, informasi, sarana produksi pertanian dan pemasaran (1)

8. Upaya peningkatan produktifitas agribisnis komoditas unggul

a. Penyuluh pertanian lapangan mengupayakan peningkatan produktifitas agribisnis komoditas unggul (3)

b. Penyuluh pertanian lapangan kurang mengupayakan peningkatan produktifitas agribisnis komoditas unggul (2)

c. Penyuluh pertanian lapangan tidak mengupayakan peningkatan produktifitas agribisnis komoditas unggul (1)

9. Upaya peningkatan pendapatan dan kesejahteraan petani padi sawah

a. Penyuluh pertanian lapangan mengupayakan peningkatan pendapatan petani dan kesejahteraan petani padi sawah (3) 
b. Penyuluh pertanian lapangan kurang mengupayakan peningkatan pendapatan petani dan kesejahteraan petani padi sawah (2)

c. Penyuluh pertanian lapangan tidak mengupayakan peningkatan pendapatan petani dan kesejahteraan petani padi sawah (1).

Variabel-variabel penunjang sebagai berikut:

1. Umur (tahun)

2. Jenis Kelamin

3. Tingkat pendidikan

4. Pengalaman Berusahatani

5. Keanggotaan dalam kelompok tani

6. Keaktifan dalam kegiatan penyuluhan

7. Luas dan status pemilikan lahan

8. Tingkat pendapatan petani

\section{Analisis Data}

Analisis data yang dilakukan dalam penelitian adalah analisis deskripstif dengan menggunakan Skala Likert. Skala likert digunakan untuk mengukur sikap, pendapat dan persepsi seseorang atau kelompok orang tentang fenomena seseorang, Soegiyono dalam Sunyoto (2014). Skala Likert digunakan untuk mengukur persepesi petani terhadap kinerja penyuluh dalam Skala Likert, maka variabel yang diukur dijabarkan menjadi indikator variabel. Kemudian indikator tersebut dijadikan sebagai titik tolak untuk menyusun item-item instrument yang dapat berupa pertanyaan-pertanyaan. Dalam penelitian ini disusun 9 pertanyaan dengan total responden 20 orang. Jawaban setiap instrument yang menggunakan Skala Likert diungkapkan dengan kata-kata berikut :

$$
\begin{array}{ll}
\text { S3 } & =\text { Sangat Puas } \\
\text { S2 } & =\text { Puas } \\
\text { S1 } & =\text { Tidak Puas }
\end{array}
$$

Dengan cara perhitungan skor masing-masing pertanyaan :

Jumlah skor tiap kriteria = capaian skor $\mathrm{X}$ jumlah responden

$$
\begin{aligned}
& \mathrm{S} 3=3 \mathrm{X} 20=60 \\
& \mathrm{~S} 2=2 \mathrm{X} 20=40 \\
& \mathrm{~S} 1=1 \mathrm{X} 20=20
\end{aligned}
$$

Jumlah skor ideal setiap pertanyaan (skor tertinggi) $=60$ (Sangat Puas)

Jumlah skor rendah $=2$

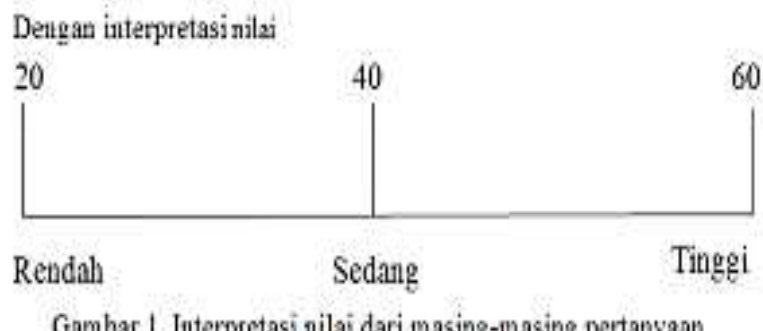

Gambar 1. Interpretasi nilai dari masing-masing pertanyaan
Cara perhitungan skor keseluruhan untuk mengetahui persepsi petani :

Jumlah Skor Seluruh Kriteria = capaian skor X jumlah responden $\mathrm{X}$ instrumen pertanyaan

$\mathrm{S} 3=3 \times 20 \times 9=540$

$\mathrm{S} 2=2 \times 20 \times 9=360$

$\mathrm{S} 1=1 \times 20 \times 9=180$

Jumlah skor ideal untuk keseluruhan pertanyaan = 540 (Sangat Puas) Jumlah skor rendah $=180$ (Tidak Puas)
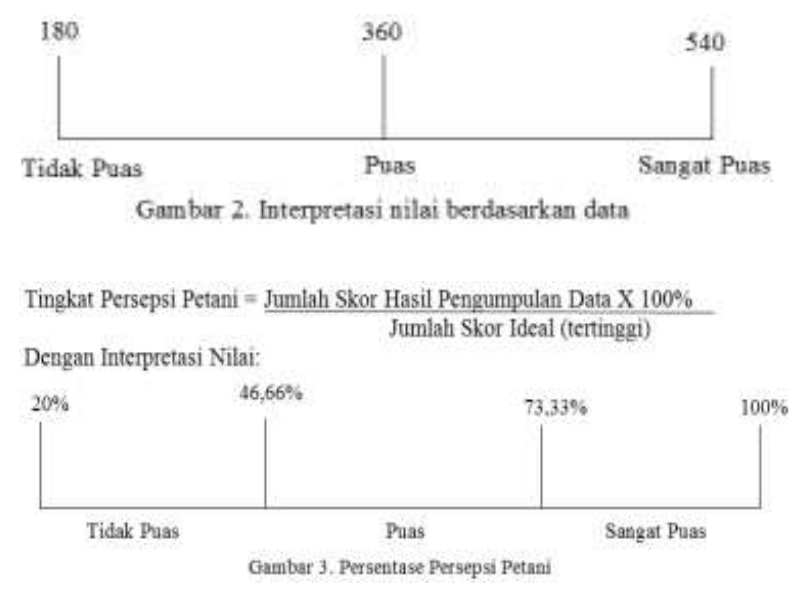

$\begin{array}{ll}\text { Angka 20\%- 46,66\% } & =\text { Tidak Puas } \\ \text { Angka 46,66\% -73,33\% } & =\text { Puas } \\ \text { Angka 73,33\%-100\% } & =\text { Sangat Puas }\end{array}$

\section{HASIL DAN PEMBAHASAN}

\section{Deskripsi Wilayah Penelitian}

\section{Letak Geografis}

Kecamatan Pusomaen merupakan Kecamatan termuda pada saat daerah Kabupatan Minahasa Tenggara dimekarkan dari Kabupaten Minahasa Selatan, dibentuk berdasarkan Peraturan Daerah Kabupaten Minahasa Selatan Nomor 18 Tahun 2005 Tentang Pembentukan Kecamatan Tatapaan, Amurang Barat, Amurang Timur, Maesaan, Pusomaen. Kecamatan Pusomaen terdiri dari 15 desa, luas wilayah sebesar 5045 Ha dengan jumlah penduduk 9968 jiwa.

Wilayah Kecamatan Pusomaen memiliki berbagai potensi yang dapat dikembangkan untuk pertumbuhan ekonomi masyarakat dan juga untuk menambah sumber-sumber pendapatan asli daerah Kabupaten Minahasa Tenggara terutama dalam bidang perikanan dan kelautan, pertanian dan perkebunan, peternakan dan pariwisata.

Sumber pendapatan dalam bidang Pertanian di Kecamatan Pusomaen antara lain tanaman padi sawah, yang merupakan sumber pendapatan utama masyarakat. Luas lahan 243,5 Ha. Angka ini merupakan akumulasi dari lahan persawahan yang dimiliki oleh 7 desa di Kecamatan Pusomaen. Hal ini dapat dilihat pada Tabel 1. 
Tabel 1. Luas Lahan Persawahan dan Jumlah Petani di 7 Desa Kecamatan Pusomaen

\begin{tabular}{llcc}
\hline No. & Desa & Luas Lahan Persawahan (Ha) & Jumlah Petani \\
\hline 1 & Minanga & 11 & 135 \\
2 & Minanga Timur & 23 & 195 \\
3 & Minanga 1 & 87 & 210 \\
4 & Minanga 2 & 6.5 & 135 \\
5 & Makalu Selatan & 46 & 195 \\
6 & Tatengesan & 60 & 195 \\
7 & Tatengesan 1 & 10 & 275 \\
& Jumlah & 243.5 & 1340 \\
\hline \multicolumn{2}{l}{ Sumber: Kantor Balai Penyuluhan Pertanian (BPP) Kec. Pusomaen, 2018 }
\end{tabular}

Desa Tatengesan merupakan salah satu Desa yang terletak di Kecamatan Pusomaen dengan luas wilayah $450 \mathrm{Ha}$, yang terdiri dari empat jaga. Adapun batas-batas wilayah dari Desa Tatengesan yaitu:

\section{Sebelah Utara : Desa Tatengesan 1 (satu) / Bentenan \\ 2. Sebelah Selatan : Laut Maluku / Desa Tumbak \\ 3. Sebelah Barat : Desa Makalu-Selatan \\ 4. Sebelah Timur : Laut Maluku/ Desa Tumbak}

Secara letak geografis Desa Tatengesan memiliki ketinggian 300 Mdpl (Meter dari permukaan laut), dengan kemiringan $60 \%$.

\section{Keadaan Penduduk}

Keseluruhan jumlah penduduk yang berada di Desa Tatengesan 604 jiwa. Tabel 2 menunjukan jumlah penduduk berdasarkan jenis kelamin di Desa Tatengesan.

\begin{tabular}{|c|c|c|c|}
\hline No. & Jenis Kelamin & JumlahPenduduk (Orang) & Persentase (\%) \\
\hline 1. & Laki-laki & 312 & 51.65 \\
\hline 2. & Perempuan & 292 & 48.34 \\
\hline & Jumlah & 604 & 100 \\
\hline
\end{tabular}

Tabel 2 Menunjukkan jumlah penduduk berjenis kelamin, laki-laki sebanyak 312 jiwa $(51.65 \%)$ dan jumlah penduduk berjenis kelamin perempuan sebanyak 292 jiwa (48.34\%), yang tersebar dalam 4 (empat) jaga.

\section{Jumlah Penduduk Berdasarkan Tingkat Pendidikan}

Jumlah penduduk berdasarkan tingkat pendidikan sebanyak 604 jiwa. Tabel 3 menunjukkan jumlah penduduk berdasarkan tingkat pendidikan yang ada di Desa Tatengesan.

\begin{tabular}{clcc}
\multicolumn{5}{l}{ Tabel 3. Jumlah Penduduk Berdasarkan Tingkat Pendidikan } \\
\hline No. & Tingkat Pendidikan & Jumlah (orang) & Persentase(\%) \\
\hline 1 & Tidak Tamat SD & 102 & 16.70 \\
2 & Tamat SD & 133 & 21.73 \\
3 & SLTP/SMP & 278 & 46.30 \\
4 & SLTA/SMA & 73 & 11.93 \\
5 & Perguruan Tinggi & 18 & 2.94 \\
\hline & Jumlah & 604 & 100 \\
\hline
\end{tabular}

Tabel 3 menunjukkan jumlah penduduk berdasarkan tingkat pendidikan terendah pada perguruan tinggi $18(2,94 \%)$ responden sedangkan tertinggi pada SLTP/SMP 278 (46,30\%) responden.

\section{Karakteristik Responden}

\section{Umur Responden}

Cara berpikir seseorang, kemampuan dalam bekerja, atau melakukan aktivitas secara fisik di pengaruhi oleh faktor umur. Begitu juga dengan para petani dengan melakukan perkerjaannya. Petani yang memiliki umur yang lebih muda memiliki kondisi fisik lebih kuat dari pada petani yang berumur lebih tua. Distribusi responden berdasarkan umur di sajikan pada Tabel 4.

\begin{tabular}{clcc}
\multicolumn{5}{l}{ Tabel } & Distribusi Responden Berdasarkan Umur \\
\hline No. & Umur & Jumlah (orang) & Persentase(\%) \\
\hline 1 & $\leq 30$ & 3 & 15 \\
2 & $31-40$ & 6 & 30 \\
3 & $41-50$ & 7 & 35 \\
4 & $\geq 51$ & 4 & 20 \\
\hline \multicolumn{5}{l}{ Jumlah } & 20 & 100 \\
\hline \multicolumn{5}{l}{ Sumber: Diolah dari data primer, 2019 }
\end{tabular}

Umur responden termuda 26 tahun sedangkan tertua umur 53 tahun. Tabel 4 menunjukkan persentase tertinggi responden pada usia 31-50 tahun (65\%) responden pada usia $\leq 30$ tahun $(15 \%)$ responden.

\section{Jumlah Responden Berdasarkan Jenis Kelamin}

Jenis kelamin merupakan dalah satu faktor penentu dalam bekerja. Laki-laki biasanya memiliki kemampuan fisik lebih kuat dibandingkan perempuan. Demikian juga dengan petani dalam melakukan pekerjaanya, dari hasil penelitian di Desa Tatengesan jumlah petani laki-laki lebih banyak dari petani perempuan. Distribusi responden berdasarkan jenis kelamin di sajikan pada Tabel 5.

\begin{tabular}{llll}
\multicolumn{3}{l}{ Tabel 5. Distribusi Responden Berdasarkan Jenis Kelamin } \\
\hline No. & Jenis Kelamin & Jumlah (orang) & Persentase(\%) \\
\hline 1 & Laki-laki & 19 & 95 \\
2 & Perempuan & 1 & 5 \\
\hline & Jumlah & 20 & 100 \\
\hline \multicolumn{2}{l}{ Sumber: Diolah dari data primer, 2019}
\end{tabular}

Tabel 5 menunjukkan bahwa jumlah resonden laki-laki lebih banyak berjumlah 19 (95\%), dan responden yang berjenis kelamin perempuan berjumlah $1(5 \%)$.

Jumlah Responden Berdasarkan Tingkat Pendidikan

Pendidikan formal sangat penting dalam peningkatan kualitas seseorang dalam cara berpikir, peningkatan intelektual dan wawasan seseorang. Berdasarkan hasil penelitian, tingkat pendidikan petani di Desa Tatengesan hanya dari Sekolah Dasar (SD), Sekolah Menengah Pertama (SLTP/SMP), dan Sekolah Menengah Atas (SLTA/SMA). Distribusi responden berdasarkan tingkat pendidikan dapat di lihat pada Tabel 6. 


\begin{tabular}{clcc}
\multicolumn{5}{c}{ Tabel 6. Distribusi Responden Berdasarkan Tingkat Pendidikan } \\
\hline No. & Tingkat Pendidikan & Jumlah (orang) & Persentase $(\%)$ \\
\hline 1 & SD & 9 & 45 \\
2 & SLTP/SMP & 8 & 40 \\
3 & SLTA/SMA & 3 & 15 \\
4 & Perguruan Tinggi & 0 & 0 \\
\hline & Jumlah & 20 & 100 \\
\hline
\end{tabular}

Sumber: Diolah dari data primer, 2019

Tabel 6 menunjukkan distribusi responden berdasarkan tingkat pendidikan pada terbanyak pada tingkat SD $9(45 \%)$ responden, dan tersedikit pada tingkat SLTA/SMA berjumlah $3(15 \%)$ responden. Belum ada petani yang lulus Perguruan Tinggi.

\section{Jumlah Responden Berdasarkan Pengalaman Bertani}

Aktivitas bertani dapat diukur dari pengalamannya. Semakin lama pengalaman bertani, semakin luas wawasan patani dalam bekerja. Distribusi responden berdasarkan pengalaman bertani dapat dilihat pada Tabel 7.

\begin{tabular}{llcc}
\multicolumn{4}{l}{ Tabel 7. Distribusi Responden Berdasarkan Pengalaman Bertani } \\
\hline No. & $\begin{array}{c}\text { Pengalaman Bertani } \\
\text { (Tahun) }\end{array}$ & $\begin{array}{c}\text { Jumlah (orang) } \\
\text { Persentase }(\%)\end{array}$ \\
\hline 1 & $1-5$ & 1 & 5 \\
2 & $6-10$ & 5 & 25 \\
3 & $11-20$ & 14 & 70 \\
\hline & Jumlah & 20 & 100 \\
\hline
\end{tabular}

Sumber : Diolah dari data primer, 2019

\section{Jumlah Responden Berdasarkan Ada/Tidaknya Keanggotaan Dalam Kelompok Tani}

Kelompok tani adalah beberapa orang petani yang menghimpun diri dalam suatu kelompok karena memiliki kesamaan dalam tujuan, motif, dan minat. Kelompok tani dibentuk berdasarkan surat keputusan dan dibentuk dengan tujuan sebagai wadah komunikasi antarpetani. Distribusi responden berdasarkan ada/tidak-nya keanggotaan dalam kelompok tani dapat pada Tabel 8 .

Tabel 8. Distribusi Responden Berdasarkan Ada/Tidaknya Keanggotaan Dalam Kelompok Tani

\begin{tabular}{llcc}
\multicolumn{4}{c}{ Dalam Kelompok Tani } \\
\hline No. & Keanggotaan & Jumlah (orang) & Persentase (\%) \\
& Kelompok Tani & & \\
\hline 1 & Ada & 10 & 50 \\
2 & Tidak & 10 & 50 \\
\hline & Jumlah & 20 & 100 \\
\hline
\end{tabular}

Sumber: Diolah dari data primer, 2019

Tabel 8 menunjukkan distribusi responden berdasarkan ada/tidak-nya keanggotaan dalam kelompok tani, hasilnya adalah sama banyak. Ada kelompok tani berjumlah 10 responden (50\%) dan tidak ada kelompok tani berjumlah 10 responden $(50 \%)$.

\section{Jumlah Responden Berdasarkan Keaktifan Dalam Kegiatan Penyuluhan}

Keaktifan dalam kegiatan penyuluhan sangatlah penting bagi petani, guna meningkatkan wawasan dan sebagai media belajar. Distribusi responden berdasarkan keaktifan dalam kegiatan penyuluhan dapat dilihat pada Tabel 9.
Tabel 9. Distribusi Responden Berdasarkan Keaktifan Dalam

\begin{tabular}{llcc}
\multicolumn{2}{c}{ Kegiatan Penyuluhan } & & \\
\hline No & Keaktifan Dalam & Jumlah (orang) & Persentase (\%) \\
& Kegiatan Penyuluhan & & \\
\hline 1 & Aktif & 8 & 60 \\
2 & Tidak Aktif & 12 & 100 \\
\hline \multicolumn{2}{l}{ Jumlah } & 20 &
\end{tabular}

Tabel 9 menunjukkan distribusi responden berdasarkan keaktifan dalam kegiatan penyuluhan terbanyak pada tidak aktif berjumlah 12 responden $(60 \%)$ dan yang aktif berjumlah 8 responden $(40 \%)$

\section{Jumlah Responden Berdasarkan Status Kepemilik- an Lahan}

Komoditas padi sawah adalah salah satu tanaman pangan yang sangat penting dan strategis kedudukannya sebagai sumber penyediaan kebutuhan pangan pokok yaitu berupa beras. Dalam tatanan pertanian pedesaan, secara garis besar sistem penguasaan lahan dapat diklasifikasikan statusnya menjadi hak milik, sewa, sakap (bagi hasil), dan gadai. Status hak milik adalah lahan yang dikuasai dan dimiliki oleh perorangan atau kelompok atau lembaga atau organisasi. Dalam perbedaan sistem kepemilikan lahan ini tentunya akan menimbulkan perbedaan dalam penerimaan petani. Selain itu tingkat pendapatan dan tingkat efisiensi pada usahatani mereka akan berbeda pula.

Tabel 10. Dsitribusi Responden Berdasarkan Status Kepemilikan Lahan Pertanian di Desa Tatengesan

\begin{tabular}{llcc}
\multicolumn{4}{c}{ Lahan Pertanian di Desa Tatengesan } \\
\hline \multirow{2}{*}{ No } & Kepemilikan & Jumlah (orang) & Persentase (\%) \\
& Lahan & & \\
\hline 1 & Pemilik & 4 & 20 \\
2 & Penggarap & 20 & 80 \\
\hline & Jumlah & 20 & 100 \\
\hline
\end{tabular}

Sumber: Diolah dari data primer, 2019

Tabel 10 menunjukkan distribusi responden berdasarkan status kepemilikan lahan tertinggi pada petani penggarap $20(80 \%)$ responden dan terendah pada petani pemilik $4(20 \%)$ responden.

\section{Jumlah Responden Berdasarakan Pendapatan}

Hasil produksi dan penjualan sangat berpengaruh terhadap pendapatan petani. Semakin tinggi hasil produksi maka pendapatan petani dari hasil penjualan baik, sedangkan semakin rendah hasil produksi pendapatan petani dari hasil penjualan juga menurun. Pendapatan petani dari setiap masa pasca panen tidak menetap.

\begin{tabular}{llll}
\multicolumn{4}{l}{ Tabel 11. Distribusi Responden Berdasarkan Pendapatan Petani } \\
\hline No. & $\begin{array}{c}\text { Jumlah Pendapatan } \\
\text { (/bln) }\end{array}$ & Jumlah (orang) & Persentase (\%) \\
\hline 1 & $\leq$ Rp.2.000.000 & 3 & 15 \\
2 & Rp.2.000.000- & 6 & 30 \\
& Rp.3.000.000 & & 55 \\
3 & $\geq$ Rp.3.000.000 & 11 & 100 \\
\hline \multicolumn{2}{l}{ Sumber: Diolah dari data primer, 2019 } & 20 &
\end{tabular}


Tabel 11 menunjukkan distribusi responden berdasarkan pendapatan petani yang terendah $\leq$ Rp.2.000.000 berjumlah $3(15 \%)$ responden, dan tertinggi pada pendapatan $\geq$ Rp.3.000.000 berjumlah $11(55 \%)$ responden.

\section{Persepsi Petani Padi Sawah Terhadap Kinerja Penyuluh Pertanian}

\section{Program Penyuluh Pertanian}

Tabel 12 menunjukkan 11 responden (55\%) menyatakan program penyuluh pertanian sesuai dengan kebutuhan petani, ada 6 responden (30\%) yang menyatakan program penyuluh pertanian hanya sebagai dasar kebutuh petani Dan yang paling sedikit ada 3 responden (15\%) yang menyatakan program penyuluh pertanian tidak sesuai dengan kebutuhan kesesuaian program penyuluhan dengan kebutuhan petani, menurut 11 dari 20 responden merasa sangat puas dengan kinerja dari penyuluh lewat program penyuluhan pertanian dan 11 responden memberi skor 3. Sedangkan 6 responden memberi skor 2, dan 3 responden memberi skor 1 . Kinerja penyuluh dalam penyusunan program menurut responden sudah sesuai dengan kebutuhan petani. Penyusunan program penyuluh pertanian sangat penting untuk penyelenggaraan dilapangan. Program penyuluh pertanian yang tidak ada dapat menyebabkan tidak adanya program jelas untuk memfasilitasi penyelenggaraan penyuluh, tidak dapat mengetahui dengan jelas permasalahan yang dihadapi petani yang berada di wilayah kerja. Total skornya adalah 48 . Angka indeks persepsi mengenai pertanyaan nomor 1 adalah tinggi, dengan interpretasi nilai $48 / 60 \times 100=90$ $\%$. Persepsi petani sangat puas terhadap kinerja penyuluh lewat program penyuluh pertanian.

\begin{tabular}{|c|c|c|c|c|c|}
\hline \multirow{2}{*}{$\begin{array}{l}\text { Tabe } \\
\text { No. }\end{array}$} & \multicolumn{2}{|c|}{$\begin{array}{l}\text { 12. Distribusi Responden Ber } \\
\text { Penyuluhan Pertanian }\end{array}$} & rkan $P$ & si Terhadap & rogram \\
\hline & $\begin{array}{l}\text { Program Penyuluh } \\
\text { Pertanian }\end{array}$ & $\begin{array}{l}\text { Alternatif } \\
\text { Skor }\end{array}$ & $\begin{array}{l}\text { Jumlah } \\
\text { (orang) }\end{array}$ & $\begin{array}{c}\text { Persentase } \\
(\%)\end{array}$ & $\begin{array}{l}\text { Total } \\
\text { Skor }\end{array}$ \\
\hline 1. & $\begin{array}{l}\text { Sesuai dengan } \\
\text { kebutuhan petani }\end{array}$ & 3 & 11 & 55 & 33 \\
\hline 2. & $\begin{array}{l}\text { Hanya sebagai } \\
\text { dasar kebutuhan } \\
\text { patani }\end{array}$ & 2 & 6 & 30 & 12 \\
\hline 3. & $\begin{array}{l}\text { Tidak sesuai } \\
\text { dengan kebutuhan } \\
\text { petani }\end{array}$ & 1 & 3 & 15 & 3 \\
\hline & Jumlah & & 20 & 100 & 48 \\
\hline
\end{tabular}

\section{Rencana Kerja Penyuluh Pertanian}

Tabel 13 menunjukkan bahwa terbanyak 10 responden $(50 \%)$ menyatakan ada rencana kerja penyuluh lengkap di wilayah, 9 responden $(45 \%)$ menyatakan ada rencana kerja tetapi tidak lengkap, dan yang paling sedikit 1 responden (5\%) menyatakan tidak ada rencana kerja penyuluh. Rencana kerja penyuluh pertanian didapat dari hasil penyusunan programa. Rencana kerja meliputi segala jenis permasalah yang ada dilapangan beserta pemecahan masalahnya. Tanpa rencana kerja penyuluh akan mendapat kesulitan dilapangan dan menyebabkan petani tidak mendapat solusi untuk masalah yang dihadapi. Menurut beberapa responden rencana kerja yang dibuat atau yang telah disusun dan sementara dijalankan sesuai dengan permasalahan dilapangan. dari total skor yang didapat adalah 49. Angka indeks persepsi mengenai pertanyaan nomor 2 adalah tinggi, dengan interpretasi nilai 49/60×100 $=81,66$ $\%$. Persepsi petani sangat puas terhadap kinerja penyuluh lewat rencana kerja penyuluh pertanian.

\begin{tabular}{|c|c|c|c|c|c|}
\hline Tabel & $\begin{array}{l}\text { 13. Distribusi Res } \\
\text { Penyuluh Perta }\end{array}$ & $\begin{array}{l}\text { den Berdasarkan } \\
\text { n }\end{array}$ & Persepsi & Terhadap Rencana & Kerja \\
\hline No. & $\begin{array}{c}\text { Rencana Kerja } \\
\text { Penyuluh Pertanian }\end{array}$ & $\begin{array}{l}\text { Alternatif } \\
\text { Skor }\end{array}$ & $\begin{array}{l}\text { Jumlah } \\
\text { (orang) }\end{array}$ & $\begin{array}{l}\text { Persentase } \\
(\%)\end{array}$ & $\begin{array}{l}\text { Total } \\
\text { Skor }\end{array}$ \\
\hline 1. & $\begin{array}{l}\text { Ada rencana kerja } \\
\text { penyuluh lengkap } \\
\text { diwilayah }\end{array}$ & 3 & 10 & 50 & 30 \\
\hline 2. & $\begin{array}{l}\text { Ada rencana kerja } \\
\text { tetapi tidak } \\
\text { lengkap }\end{array}$ & 2 & 9 & 45 & 18 \\
\hline \multirow[t]{2}{*}{3.} & $\begin{array}{l}\text { Tidak ada rencana } \\
\text { kerja }\end{array}$ & 1 & 1 & 5 & 1 \\
\hline & $\begin{array}{l}\text { Jumlah } \\
\end{array}$ & & 20 & 100 & 49 \\
\hline
\end{tabular}

Sumber: Diolah dari data primer, 2019

\section{Peta Wilayah Untuk Pengembangan Teknologi Dan Perwilayahan Komoditi Unggul}

Tabel 14 menunjukkan bahwa 4 responden (20\%) menyatakan ada peta wilayah kerja lengkap untuk pengembangan teknologi dan komoditi unggul, 14 responden $(70 \%)$ menyatakan ada peta wilayah kerja tetapi tidak lengkap dan 2 responden $(10 \%)$ menyatakan tidak ada peta wilayah kerja untuk pengembangan teknologi dan komoditi unggul. Peta wilayah untuk pengembangan menurut sebagian besar responden merasa puas dengan kebutuhan petani. Pembuatan peta wilayah kerja untuk mengetahui permasalahan apa yang ada dilapangan dan yang membuat petani mendapat kendala, dan juga penyuluh bisa mengetahui potensi komoditi diwilayah kerja. Identifikasi potensi wilayah pengembangan teknologi dan komoditi unggul merupakan data dasar yang harus dipunyai penyuluh pertanian, diketahuinya potensi dan masalah serta solusi pemecahan masalah yang akan diberikan oleh penyuluh pertanian yang nantinya akan dituangkan dalam programa penyuluhan. Mengembangkan kemampuan dan inovasi teknologi sangat penting, untuk itu penyuluh harus turun langsung kelapangan dan melihat masalah apa saja yang ada sehingga ada keterkaitan dengan pengembangan inovasi teknologi dan wilayah mana yang mempunyai komoditi unggul. Total skor pada pertanyaan nomor 3 adalah 38. Angka indeks persepsi mengenai pertanyaan nomor 3 adalah sedang, dengan interpretasi nilai $42 / 60 \times 100=70 \%$. Persepsi petani puas terhadap kinerja penyuluh lewat peta wilayah kerja untuk pengembangan teknologi dan perwilayahan komoditi unggul. 


\begin{tabular}{|c|c|c|c|c|c|c|}
\hline No & $\begin{array}{l}\text { Peta Wilayah } \\
\text { Pengembangan } \\
\text { Dan Perwilayah } \\
\text { Unggul }\end{array}$ & $\begin{array}{r}\text { Untuk } \\
\text { Teknologi } \\
\text { Komoditi }\end{array}$ & $\begin{array}{c}\text { Alternatif } \\
\text { Skor }\end{array}$ & $\begin{array}{l}\text { Jumlah } \\
\text { (orang) }\end{array}$ & $\begin{array}{c}\text { Persentase } \\
(\%)\end{array}$ & $\begin{array}{l}\text { Total } \\
\text { Skor }\end{array}$ \\
\hline 1 & $\begin{array}{l}\text { Ada peta wilayah k } \\
\text { lengkap }\end{array}$ & & 3 & 4 & 20 & 12 \\
\hline 2 & $\begin{array}{l}\text { Ada peta wilayah, t } \\
\text { lengkap }\end{array}$ & api tidak & 2 & 14 & 70 & 28 \\
\hline 3 & Tidak ada peta wila & iyah & 1 & 2 & 10 & 2 \\
\hline & Jumlah & & & 20 & 100 & 42 \\
\hline
\end{tabular}

\section{Penyebaran Teknologi Pertanian}

Tabel 15 menunjukkan bahwa 4 responden (20\%) menyatakan penyebaran teknologi pertanian merata, 13 responden $(65 \%)$ menyatakan penyebaran teknologi pertanian tidak merata dan 3 responden (15\%) menyatakan tidak ada penyebaran teknologi pertanian. Penyebaran teknologi pertanian kurang merata dan cukup sesuai dengan kebutuhan petani. Tugas penyuluh pertanian adalah melakukan pelatihan dan memberikan informasi apabila ada inovasi teknologi, dengan adanya pelatihan dan informasi tentang teknologi yang baru petani dapat meningkatkan kemampuan dalam bercocok tanam. Petani menilai penyebaran informasi cukup sesuai dengan kebutuhan petani, untuk itu total skornya ada 41 Angka indeks persepsi mengenai pertanyaan nomor 4 adalah sedang, dengan interpretasi nila $41 / 60 \times 100=68,3 \%$. Persepsi petani puas terhadap kinerja penyuluh lewat penyebaran teknologi pertanian.

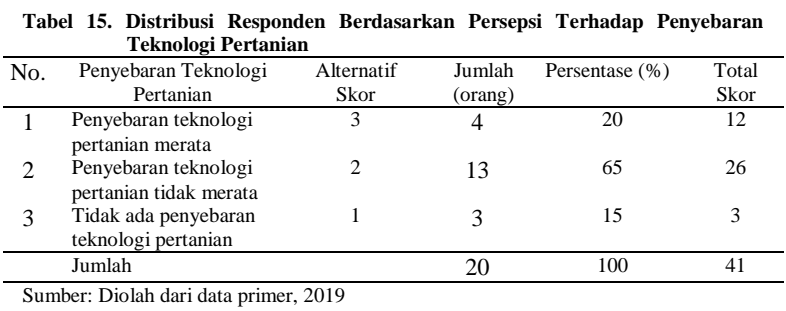

\section{Upaya Penyuluh Pertanian Lapangan Untuk Meningkatkan Daya Saing Petani}

Tabel 16 menunjukkan 2 responden (10\%) menyatakan punyuluh pertanian lapangan berupaya meningkatkan daya saing petani, 7 responden (35\%) menyatakan penyuluh pertanian lapangan kurang berupaya meningkatkan daya saing petani dan 11 responden $(55 \%)$ menyatakan penyuluh pertanian lapangan tidak berupaya meningkatkan daya saing petani karena petani yang memotivasi dan mencari peluang sendiri untuk meningkatkan daya saing. Untuk itu total skornya ada 41 Angka indeks persepsi mengenai pertanyaan nomor 5 adalah sedang, interpretasi nilai $31 / 60 \times 100=51,66 \%$. Persepsi petani puas terhadap kinerja penyuluh lewat upaya penyuluh pertanian lapangan untuk meningkatkan daya saing petani.

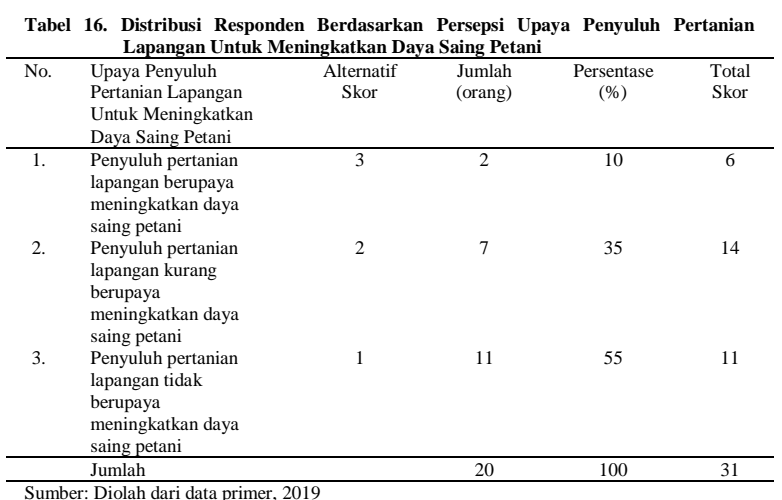

Upaya Penyuluh Pertanian Lapangan Untuk Menjalin Kemitraan Petani Dengan Pengusaha

Tabel 17 menunjukkan 3 responden (15\%) menyatakan penyuluh pertanian lapangan kurang mengupayakan kemitraan petani dengan pengusaha dan 17 responden (85\%) menyatakan penyuluh pertanian lapangan tidak mengupayakan kemitraan petani dengan pengusaha. Dengan alasan penyuluh hanya memberi motivasi saat kegiatan penyuluhan tetapi penerapan langsung dilapangan kurang, sehingga petani secara mandiri mencari mitra untuk penjualan. Untuk itu total skornya ada 23 Angka indeks persepsi mengenai pertanyaan nomor 6 adalah rendah yaitu $23 / 60 \times 100=38,33 \%$. Persepsi petani tidak puas terhadap kinerja penyuluh untuk menjalin kemitraan petani dengan pengusaha.

\begin{tabular}{|c|c|c|c|c|c|c|c|}
\hline Tabe & el 17. & $\begin{array}{c}\text { Distribusi } \\
\text { Penyuluh } \\
\text { Kemitraa }\end{array}$ & $\begin{array}{r}\text { Respon } \\
\text { Perta } \\
\text { in Petani }\end{array}$ & $\begin{array}{l}\text { en Berd } \\
\text { lan La } \\
\text { engan Pe }\end{array}$ & $\begin{array}{l}\text { sarkan } \\
\text { angan } \\
\text { igusaha }\end{array}$ & $\begin{array}{c}\text { Terhadap } \\
\text { Untuk }\end{array}$ & $\begin{array}{l}\text { Persepsi } \\
\text { Menjalin }\end{array}$ \\
\hline No. & $\begin{array}{l}\text { Upaya } \\
\text { Lapangan } \\
\text { Kemitraar } \\
\text { Pengusah: }\end{array}$ & $\begin{array}{l}\text { Penyuluh } \\
\text { Untuk } \\
\text { Petani } \\
\end{array}$ & $\begin{array}{r}\text { Pertanian } \\
\text { Menjalin } \\
\text { Dengan }\end{array}$ & $\begin{array}{l}\text { Alternatif } \\
\text { Skor }\end{array}$ & $\begin{array}{l}\text { Jumlah } \\
\text { (orang) }\end{array}$ & $\begin{array}{c}\text { Persentase } \\
(\%)\end{array}$ & $\begin{array}{l}\text { Total } \\
\text { Skor }\end{array}$ \\
\hline 1 & $\begin{array}{l}\text { Penyuluh } \\
\text { tetap mer } \\
\text { petani den }\end{array}$ & $\begin{array}{c}\text { pertanian } \\
\text { ngupayakan } \\
\text { gan pengusah }\end{array}$ & $\begin{array}{l}\text { lapangan } \\
\text { kemitraan } \\
\text { aa }\end{array}$ & 3 & 0 & 0 & 0 \\
\hline 2 & $\begin{array}{l}\text { Penyuluh } \\
\text { kurang } \\
\text { kemitraan } \\
\text { pengusah }\end{array}$ & $\begin{array}{c}\text { pertanian } \\
\text { meng } \\
\text { petani }\end{array}$ & $\begin{array}{r}\text { lapangan } \\
\text { upayakan } \\
\text { dengan }\end{array}$ & 2 & 3 & 15 & 6 \\
\hline 3 & $\begin{array}{l}\text { Penyuluh } \\
\text { tidak mer } \\
\text { petani den }\end{array}$ & $\begin{array}{c}\text { pertanian } \\
\text { ngupayakan } \\
\text { gan pengusah }\end{array}$ & $\begin{array}{l}\text { lapangan } \\
\text { kemitraan } \\
\text { aa } \\
\end{array}$ & 1 & 17 & 85 & 17 \\
\hline & Jumlah & & & & 20 & 100 & 23 \\
\hline
\end{tabular}

Upaya Penyuluh Pertanian Lapangan Membuka Akses Petani ke Lembaga Keuangan, Informasi, Sarana Produksi dan Pemasaran

Tabel 18 menunjukkan 2 responden (10\%) menyatakan penyuluh pertanian lapangan kurang mengupayakan membuka akses petani ke lembaga keuangan, informasi, sarana produksi pertanian dan pemasaran dan ada 18 responden (90\%) yang menyatakan penyuluh pertanian lapangan tidak mengupayakan membuka akses petani ke lembaga keuangan, informasi, sarana produksi pertanian dan pemasaran. Karena salah satu tujuan petani adalah untuk mencari modal melalui lembaga keuangan 
terutama membutuhkan koperasi di desa dan juga kios-kios sarana produksi untuk mengakses kebutuhan petani. Untuk itu kebanyakan responden memberikan skor 1 karena yang terjadi dilapangan petani yang mengusahakan sendiri modal dan penjualan hasil produksi. Untuk itu total skornya ada 22, angka indeks persepsi mengenai pertanyaan nomor 7 adalah rendah, yaitu 22/60x100 $=36,66 \%$. Persepsi peatani tidak puas terhadap kinerja penyuluh membuka akses petani ke lembaga keuangan, informasi, sarana produksi dan pemasaran.

\begin{tabular}{|c|c|c|c|c|c|}
\hline Tabel & $\begin{array}{l}\text { Distribusi Responden Be } \\
\text { Penyuluh Pertanian La } \\
\text { Lembaga Keuangan, Info }\end{array}$ & $\begin{array}{l}\text { lasarkan } \\
\text { angan M } \\
\text { asi, Saran }\end{array}$ & $\begin{array}{l}\text { Persepsi } \\
\text { lembuka } \\
\text { la Produk }\end{array}$ & $\begin{array}{l}\text { Terhadap I } \\
\text { Akses Peta } \\
\text { si dan Pemas }\end{array}$ & $\begin{array}{l}\text { payah } \\
\text { ii Ke } \\
\text { iran }\end{array}$ \\
\hline No. & $\begin{array}{l}\text { Upaya Penyuluh Pertanian } \\
\text { Lapangan Membuka Akses } \\
\text { Petani ke Lembaga Keuangan, } \\
\text { Informasi, Sarana Produksi dan } \\
\text { Pemasaran }\end{array}$ & $\begin{array}{l}\text { Alternatif } \\
\text { Skor }\end{array}$ & $\begin{array}{l}\text { Jumlah } \\
\text { (orang) }\end{array}$ & $\begin{array}{c}\text { Persentase } \\
(\%)\end{array}$ & $\begin{array}{r}\text { Total } \\
\text { Skor }\end{array}$ \\
\hline 1. & $\begin{array}{lr}\text { Penyuluh pertanian } & \text { lapangan } \\
\text { tetap mengupayakan } & \text { membuka } \\
\text { akses petani ke lembaga } \\
\text { keungan,informasi,sarana } \\
\text { produksi pertanian } \\
\text { pemasaran dan }\end{array}$ & 3 & 0 & 0 & 0 \\
\hline 2. & $\begin{array}{l}\text { Penyuluh pertanian lapangan } \\
\text { kurang mengupayakan membuka } \\
\text { akses petani ke lembaga } \\
\text { keuangan,informasi,sarana } \\
\text { produksi pertanian dan } \\
\text { pemasaran }\end{array}$ & 2 & 2 & 10 & 4 \\
\hline 3. & $\begin{array}{l}\text { Penyuluh pertanian lapangan } \\
\text { tidak mengupayakan membuka } \\
\text { akses petani ke lembaga } \\
\text { keuangan,informasi,sarana } \\
\text { produksi pertanian dan } \\
\text { pemasaran } \\
\end{array}$ & 1 & 18 & 90 & 18 \\
\hline & Jumlah & & 20 & 100 & 22 \\
\hline
\end{tabular}

\section{Upaya Peningkatan Produktifitas Agribisnis Komoditi Unggul}

Tabel 19 menunjukkan 3 responden (15\%) menyatakan penyuluh pertanian lapangan mengupayakan peningkatan produktifitas agribisnis komoditi unggul, 4 responden $(20 \%)$ menyatakan penyuluh pertanian lapangan kurang mengupayakan peningkatan produktifitas agribisnis komoditi unggul, dan ada 13 responden (65\%) mengatakan penyuluh pertanian lapangan tidak mengupayakan peningkatan produktifitas agribisnis komoditi unggul. Total Skor terendah adalah 30. Alasan responden karena penyuluh pertanian lapangan tidak mengupayakan peningkatan produktifitas agribisnis komuditas unggul. Peningkatan produktifitas agribisnis sangat diperlukan, jika produktifitas agribisnis meningkat maka pendapatan dan kesejahteraan petani juga cenderung meningkat. Walaupun ada kegiatan penyuluhan pertanian di desa produktifitas agribisnis tidak meningkat karena sebagian besar petani masih menggunakan cara-cara tradisional. Untuk itu total skornya 30 angka dengan indeks persepsi pertanyaan nomor 8 adalah rendah, yaitu $30 / 60 \times 100=50 \%$. Persepsi petani tidak puas terhadap kinerja penyuluh lewat upaya peningkatan produktifitas agribisnis komoditi unggul.
Tabel 19. Distribusi Responden Berdasarkan Persepsi Terhadap Tabel 19. Distribusi Responden Berdasarkan Persepsi Terhadap
Upaya Peningkatan Produktifitas Agribisnis

\begin{tabular}{llcccc}
\multicolumn{6}{c}{ Komoditi Unggul } \\
\hline No. & $\begin{array}{l}\text { Upaya } \\
\text { Produktifitas Peningkatan } \\
\text { Komuditi Unggul }\end{array}$ & $\begin{array}{c}\text { Alternatif } \\
\text { Agribisnis }\end{array}$ & $\begin{array}{c}\text { Jumlah } \\
\text { (orang) }\end{array}$ & $\begin{array}{c}\text { Persentase } \\
(\%)\end{array}$ & $\begin{array}{c}\text { Total } \\
\text { Skor }\end{array}$ \\
\hline 1 & $\begin{array}{l}\text { Penyuluh pertanian lapangan } \\
\text { mengupayakan peningkatan } \\
\text { produktifitas agribisnis } \\
\text { komoditas unggul }\end{array}$ & 3 & 3 & 15 & 9 \\
2 & $\begin{array}{l}\text { Penyuluh pertanian lapangan } \\
\text { kurang mengupayakan } \\
\text { peningkatan produktifitas } \\
\text { agribisnis komoditas unggul } \\
\text { Penyuluh pertanian lapangan } \\
\text { tidak mengupayakan } \\
\text { peningkatan produktifitas } \\
\text { agribisnis komoditas unggul }\end{array}$ & 2 & 4 & 20 & 8 \\
\hline Jumlah & 13 & 65 & 13 \\
\hline Sumber: Diolah dari data primer, 2019 & & & \\
\hline
\end{tabular}

\section{Upaya Peningkatan Pendapatan dan Kesejahteraan Petani Padi Sawah}

Tabel 20 menunjukkan ada 1 responden $(5 \%)$ menyatakan penyuluh pertanian lapangan mengupayakan peningkatan pendapatan dan kesejahteraan petani padi sawah, 5 responden $(25 \%)$ menyatakan penyuluh pertanian lapangan kurang mengupayakan peningkatkan pendapatan dan kesejateraan petani padi sawah dan 14 responden (70\%) menyatakan penyuluh pertanian lapangan tidak mengupayakan peningkatan pendapatan dan kesejahteraan petani padi sawah. Skor terendah adalah 27. Menurut responden penyuluh pertanian lapangan tidak mengupayakan peningkatan pendapatan dan kesejahteraan petani. Pendapatan petani sesuai dengan hasil produksi agribisnis, semakin tinggi hasil produksi semakin baik pendapatan dan kesejahteraan petani semakin meningkat. Sebaliknya, jika hasil produksi agribisnis rendah, maka pendapatan petani rendah dan kesejahteraan petani menurun. Untuk itu total skornya ada 27 angka indeks persepsi mengenai pertanyaan nomor 9 adalah rendah, yaitu 27/60x 100 $=45 \%$. Persepsi petani tidak puas terhadap kinerja penyuluh lewat upaya peningkatan pendapatan petani dan kesejahteraan petani.

Tabel 20. Distribusi Responden Berdasarkan Persepsi Terhadap
Upaya Peningkatan Pendapatan Petani dan Kesejahteraan
Petani Padi Sawah




\section{Rekapitulasi Jumlah Skor Pengambilan Data dan Interpretasi Persepsi Petani Padi Sawah Terhadap Kinerja Penyuluh Pertanian}

Tabel 21 menunjukkan bahwa terdapat 9 indikator persepsi petani padi sawah terhadap kinerja penyuluh pertanian dimana pertanyaan ke-1 mendapat indeks tertinggi yaitu $80 \%$ karena, kebanyakan responden merupakan anggota kelompok tani dan aktif mengukuti kegiatan penyuluhan dan menjawab program penyuluh pertanian sesuai dengan kebutuhan petani, dan pertanyaan ke-7 mendapat indeks terendah yaitu 36,66\% karena kebanyakan petani pada masa pasca panen dengan mandiri mencari akses produksi pertanian dan penjualannya. Total skor yang diperoleh dari 9 indikator pertanyaan yang diajukan kepada 20 responden adalah 313. Persentase angka indeks Persepsi Petani Padi Sawah Terbadap Kinerja Penyuluh Pertanian di Desa Tatengesan Kecamatan Pusomaen Kabupaten Minahasa Tenggara terletak pada $313 / 540 \times 100 \%=57,96 \%$ (Sedang).

Berdasarkan hasil analisis menggunakan Skala Likert bahwa angka indeks persepsi petani padi sawah terhadap kinerja penyuluh pertanian berada pada titik $57,96 \%$ dan masuk dalam kategori sedang.

\begin{tabular}{|c|c|c|c|c|c|}
\hline & \multicolumn{4}{|c|}{$\begin{array}{l}\text { Rekapitulasi Jumlah Skor Pengambilan Data dan Interpretasi Persepsi } \\
\text { Petani Padi Sawah Terhadap Kinerja Penyuluh Pertanian }\end{array}$} \\
\hline No & & Pertanyaan & $\begin{array}{l}\text { Total } \\
\text { Skor }\end{array}$ & $\begin{array}{c}\text { Indeks } \\
\text { Persepsi }(\%)\end{array}$ & Interpretasi \\
\hline 1 & Prog & am Penyuluh Pertanian & 48 & 80 & Sangat Puas \\
\hline 2 & Renc & ana Kerja Penyuluh Pertanian & 49 & 81,66 & Sangat Puas \\
\hline 3 & $\begin{array}{l}\text { Peta } \\
\text { Tekn } \\
\text { Unge }\end{array}$ & $\begin{array}{l}\text { Wilayah Untuk Pengembangan } \\
\text { ologi Dan Perwilayahan Komoditi } \\
\text { ul }\end{array}$ & 42 & 70 & Puas \\
\hline 4 & Peny & baran Teknologi Pertanian & 41 & 68,33 & Puas \\
\hline 5 & $\begin{array}{l}\text { Upay } \\
\text { Untu }\end{array}$ & $\begin{array}{l}\text { an Penyuluh Pertanian Lapangan } \\
\text { k Meningkatkan Daya Saing Petani }\end{array}$ & 31 & 51,66 & Puas \\
\hline 6 & $\begin{array}{l}\text { Upay } \\
\text { Untu } \\
\text { Deng }\end{array}$ & $\begin{array}{l}\text { a Penyuluh Pertanian Lapngan } \\
\text { k Menjalin Kemitraan Petani } \\
\text { an Pengusaha }\end{array}$ & 23 & 38,33 & Tidak Puas \\
\hline 7 & $\begin{array}{l}\text { Upay } \\
\text { Mem } \\
\text { Keua } \\
\text { dan F }\end{array}$ & $\begin{array}{l}\text { a Penyuluh Pertanian Lapangan } \\
\text { buka Akses Petani Ke Lembaga } \\
\text { ngan, Informasi, Sarana Produksi } \\
\text { emasaran }\end{array}$ & 22 & 36,66 & Tidak Puas \\
\hline 8 & $\begin{array}{l}\text { Upay } \\
\text { Agib }\end{array}$ & $\begin{array}{l}\text { a Peningkatan Produktifitas } \\
\text { snis Komoditas Unggul }\end{array}$ & 30 & 50 & Tidak Puas \\
\hline 9 & Upay & $\begin{array}{l}\text { a Peningkatan Pendapatan Petani } \\
\text { Eesejahteraan Petani Padi Sawah }\end{array}$ & 27 & 45 & Tidak Puas \\
\hline
\end{tabular}

\section{KESIMPULAN DAN SARAN}

\section{Kesimpulan}

Persepsi petani padi sawah terhadap kinerja penyuluh pertanian di Desa Tatengesan Kecamatan Pusomaen Kabupaten Minahasa Tenggara, dilihat dari 9 indikator yaitu Persepsi Petani Sangat Puas Terhadap Kinerja Penyuluh Lewat Program Penyuluh Pertanian, Persepsi Petani Sangat Puas Terhadap Rencana Kerja Penyuluh Pertanian, Persepsi Petani Puas Terhadap Kinerja Penyuluh Lewat Peta Wilayah Untuk Pengembangan Teknologi dan Perwilayahan Komoditi Unggul, Persepsi Petani Puas Terhadap Kinerja Penyuluh Lewat Penyebaran Teknologi Pertanian, Persepsi Petani Puas Terhadap Kinerja Penyuluh Lewat
Upaya Penyuluh Pertanian Lapangan Untuk Meningkatkan Daya Saing Petani, Persepsi Petani Tidak Puas Terhadap Kinerja Penyuluh Lewat Upaya Penyuluh Pertanian Lapangan Untuk Menjalin Kemitraan Petani Dengan Pengusaha, Persepsi Petani Tidak Puas Terhadap Kinerja Penyuluh Lewat Upaya Penyuluh Pertanian Lapangan Membuka Akses Petani Ke Lembaga Keuangan, Informasi, Sarana Produksi Pertanian dan Pemasaran, Persepsi Petani Tidak Puas Terhadap Kinerja Penyulu Lewat Upaya Peningkatan Produktifitas Agribisnis Komoditas Unggul, dan Persepsi Petani Tidak Puas Terhadap Kinerja Penyuluh Lewat Upaya Peningkatan Pendapatan dan Kesejahteraan Petani. Persentase angka indeks penilaian Persepsi Terhadap Kinerja Penyuluh Pertanian Masuk dalam kategori sedang.

\section{Saran}

Saran-saran yang diharapkan dapat berguna :

1 Perlu adanya perhatian lebih dari lembaga terkait kepada penyuluh, dari hasil penelitian kinerja penyuluh di Desa Tatengesan masih belum maksimal untuk itu masih perlu adanya pembinaan dari lembaga terkait kepada penyuluh untuk meningkatkan motivasi kerja penyuluh

2 Penyuluh pertanian harus lebih peka lagi mendengar keluhan petani terhadap apa yang menjadi kendala petani di lapangan, untuk meningkatkan produktifitas agribisnis dan meningkatkan kesejahteraan petani.

3 Sangat diperlukan adanya peningkatan dan memaksimalkan kinerja dari penyuluh pertanian berdasarkan 9 indikator keberhasilan penyuluh pertanian agar pemecahan masalah petani tercapai dengan baik.

\section{DAFTAR PUSTAKA}

Animar. 2013. Persepsi Petani Padi Terhadap Kinerja Penyuluh Pertanian Di Kecamatan Suka Makmue Kabupaten Nagan Raya. Aceh Barat: Program Studi Agribisnis Fakultas Pertanian Universitas Teuku Umar Meulaboh.

Gitosaputro S, Listiana L, Gultom RT. 2012. Dasardasar Penyuluhan dan Komunikasi Pertanian. Anugrah UtamaRaharja. Bandar Lampung

Mardikanto, T. 2008. Sistem Penyuluh Pertanian. Lembaga Pengembangan Pendidikan (LLP) UNS dan UNS Press.Surakarta.

UU No. 16/2006 Tentang Sistem Penyuluh Pertanian, Perikanan, dan Kehutanan (SP3K) Pasal 4.

Van Den Ban, A.W. dan Hawkins, 1999 Penyuluh Pertanian. Kanisius Jogjakarta. 